Jakub Galuszka

\title{
Examining patterns of policy change in a post-socialist city: the evolution of inner- city regeneration approaches in Łódź, Poland, after 1989
}

Journal article | Accepted manuscript (Postprint)

This version is available at https://doi.org/10.14279/depositonce-10309

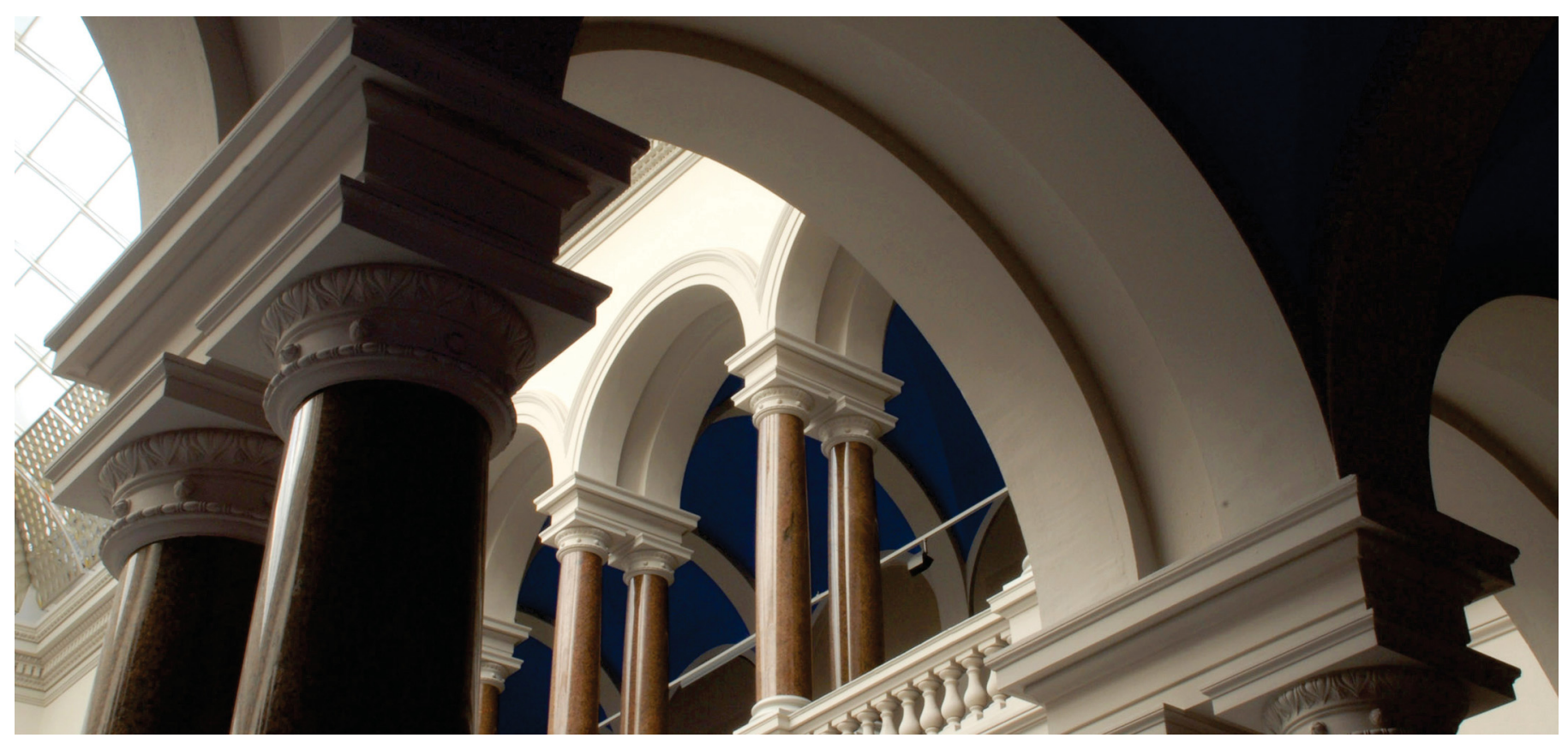

Accepted manuscript, does not include final corrections of Editorial Team. This article has been peerreviewed, accepted and published in:

Galuszka, J. (2017). Examining patterns of policy change in a post-socialist city: the evolution of innercity regeneration approaches in Łódź, Poland, after 1989. Town Planning Review, 88(6), 639-664. https://doi.org/10.3828/tpr.2017.39 


\title{
Examining patterns of policy change in a post-socialist city: the evolution of inner-city regeneration approaches in Łódź, Poland, after 1989
}

\begin{abstract}
The article analyses the process of transformation of inner-city regeneration strategies in the central Eastern European (CEE) city of Łódź in Poland. During the period of structural adjustment that commenced with the fall of socialist regime in 1989, the city experienced multiple problems linked to the closure of the textile industry, depopulation and a number of social issues. In their search for a new strategic development model, the local authorities experimented with multiple inner-city regeneration approaches. By reviewing key strategic documents in the city, this paper analyses the gradual change in the objectives and pressure points in inner-city regeneration. The analysis is complemented by the presentation of three case studies illustrating how the approaches identified within these strategies (culture-led development, mega-project, socially focused revitalisation) were implemented.
\end{abstract}

Keywords: inner-city regeneration, mega-project, post-socialist city, culture-led development, central Eastern Europe, revitalisation, Łódź, Poland

\section{Introduction}

Facing new economic and political realities in the early ig9os, the countries of the postSoviet bloc went through a rough period of structural adjustment, which left its mark on cities and their inner-city neighbourhoods. The new economic realm created both an opportunity and an aspiration for the redevelopment of urban areas. Although it is questionable whether the development process followed the same pattern in different cities in Central Eastern Europe (CEE), a few key common issues may be identified across the region. Much attention has been given to changing socio-economic and spatial characteristics of the local cities, including shrinkage, ghettoisation, gentrification and suburbanisation processes (see Kok and Kovács, I999; Sýkora, I999; Kovács, I998; Hirt, 2013; Brade et al., 2009; Marcińczak et al., 2012). Similarly, attention has been given to various inner-city regeneration projects and city-level case studies (Temelová, 2007; Kovács et al., 2012; 2015).

This article broadens the scope of the analysis of urban transformation processes in CEE by looking primarily at the evolution and relationships between different innercity regeneration approaches during the last twenty-five years in Łódź, Poland. [AQI] Section I of the article provides a theoretical background on inner-city regeneration practices in CEE in recent decades, while section 2 provides contextual information 
about Łódź. Sections 3 and 4 include a review of the main legislation and strategies relevant to inner-city regeneration and the presentation of three case studies illustrating the implementation of the identified approaches. Finally, conclusions from the study are discussed.[AQ2]

\section{Inner-city regeneration in Central and Eastern Europe}

\subsection{Context}

Shortly after the political change of the early ig9os the majority of CEE urban areas experienced similar socio-economic and spatial processes. However, the speed of transformations and the ability to address these issues varied significantly between different cities. In particular, some of the multifunctional, diverse cities like Warsaw, Krakow, Poznań and Gdańsk in Poland developed rapidly (Marcińczak et al., 2012). By the end of the I99os their picturesque inner cities were partially refurbished, although many of the regeneration attempts were limited to pedestrianisation of their central markets and renovation of the most emblematic heritage. Many of these initiatives were steered by the private sector, whose extensive involvement in urban regeneration is considered one of the key differences compared with analogous processes in Western Europe (Temelová, 2009). The liberation of previously stalled resources, restitution processes and the privatisation of the housing stock coincided with an influx of global capital. As a consequence many public authorities were highly receptive to cooperation with the private sector and engagement in private-public partnerships (Turok, I992). However, due to institutional fragmentation and weak levels of state intervention, speculative forms of redevelopment tended to hinder socially oriented interventions (Keresztély and Scott, 2012). A good example is the regeneration of the Kazimierz district in Krakow, where strong involvement of the private sector led to unintentional market- and property-led revitalisation which benefited local communities in a limited way (Murzyn, 2006). Therefore the relatively high socio-economic status and renovated centres of cities like Prague or Krakow might not necessarily just be the effect of planned public regeneration processes, but a consequence of market pressure on attractive locations or the result of the historical characteristics of a city.

Alongside these processes, public agencies in CEE started to develop their own practices to manage the challenges they faced. With time the 'Western' notions of strategic planning and urban regeneration started to play a more important role in the policy and governance practices in the local cities (Scott and Kühn, 2012). Consequently, many cities in CEE initiated various area-based projects targeting regeneration of their inner areas (Leary and McCarthy, 2013). The approaches discussed in the following section link to the case studies in Lódź and represent culture-led development, mega-projects and social revitalisation approaches. 


\subsection{Culture led-development}

Viewed in a broad sense, culture-led development can be identified as one of the prominent regeneration approaches in CEE. The contribution of culture to regeneration may include a variety of interventions ranging from major investment in festivals or flagship buildings to small-scale interventions like public arts programmes (Evans and Shaw, 2004). Several reports identifying culture and arts as a means to stop the erosion of inner-city districts had appeared already in the I98os in the United Kingdom. In the following years cities like Manchester experimented with the approach, with different cities across the globe following this trend (Kunzmann, 2004). Even though only a few of these were truly successful and the ability to emulate Manchester's success in cities like Łódź was dubious (Walker, 1993), the approach attracted attention also in CEE. Consequently, many of the local authorities invested in culture and arts in their inner cities from the Iggos onwards. On the one hand this type of project has focused on traditional heritage and included the creation of museums and cultural trails and the commercialisation of heritage (Murzyn, 2008). On the other hand, industrial urban fabric has often been reinterpreted through linkage with alternative arts, cultural events and creative industries. Both seem to be motivated by potential economic gain as well as by a symbolic need to reinvent themselves through linkage with pre-communist, capitalist traditions (Tölle, 20го). In fact, in Poland, cultural festivals are mushrooming in many primary and secondary cities. Similarly pan-European arts and cultural programmes, like the European Capital of Culture, steer many regeneration processes (i.e. in Sibiu in Romania or Pécs in Hungary). The impact of these types of intervention varies from case to case, with the examples of Krakow Capital of Culture in the year 2000 believed to increase the tourist flow in the city without having significant effects on its 'cultural life' (Hughes et al., 2003) or the smaller-scale project in Śródka, Poznan, where the introduction of artists and cultural institutions into the district has been contested by local communities (Kaczmarek and Marcińczak, 2013). When implemented in a sectoral manner without proactive and multidimensional political and public engagement, cultural interventions hardly benefit the marginalised population (Colomb, 201 I). In fact, culture-led development runs the risk of promoting gentrification specifically in the context of the emergence of new urban consumption spaces responding to new patterns of leisure and culture (Zukin, 1998) introduced in post-socialist reality after 1989.

\subsection{Mega-projects}

Another inner-city regeneration approach with relevance to Lódź is the development of mega-projects. These can be identified as high-profile projects involving the redevelopment of industrial and brownfield areas, the creation of transport 
infrastructure and the renovation of historic districts (mostly with a focus on the needs of middle- to upper-class consumers) (Orueta and Fainstein, 2008). Mega-projects tend to generate impressive budgets, public attention and general support from decision-makers. Their attractiveness was identified by Flyvbjerg (20I4) as linked to four technological, political, economic and aesthetic 'sublimes' which motivate the development of mega-projects. The stakeholders involved expect clear benefits from engaging in this type of initiative. Politically, mega-projects can result in media attention; economically, they promise new employment opportunities. They also might link to technological innovation and enable the creation of iconically beautiful buildings. However, as much as mega-projects succeed in exciting the general public, they also tend to be characterised by a failure to keep to original deadlines and budgets as well as a lack of overall transparency.

While there are privately driven initiatives like Port Praski in Warsaw, the emblematic mega-projects with significant involvement of public authorities are not yet as evident in inner cities in CEE as in the old EU countries (just to name a few: the Sagrera project in Barcelona, HafenCity in Hamburg and Stuttgart 2I in Germany). In fact, numerous iconic buildings with a cultural function have been constructed in the region and are being used as a tool to activate specific districts, but rarely emerge as mega-projects and relate more to the culture-driven regeneration approach. Similarly, many big projects involving the redevelopment of train stations are being carried out in CEE and are associated with supplementary initiatives of the private sector (like the West End City Centre in Budapest) (Peters and Novy, 2012). With land becoming more and more expensive in the major cities of CEE, train companies have started to use their valuable resources and take on the role of real-estate agents or developers. Although this kind of project might impact regeneration of some areas in a city, their main goal is the commercialisation of urban space, resulting in increasing commercial functions in the total land use area (Sykora, r999).

The mega-projects applied (or declared) as part of an inner city regeneration strategy are implemented relatively rarely, which makes the case of the New Centre of Łódź or the Europoint in Brno all the more interesting as a subject for study and evaluation.

\subsection{Socially focused revitalisation}

The last of the approaches with relevance to Łódź - socially focused revitalisation - includes comprehensive interventions which comprehensively [AQ3] address housing and issues of economic and social exclusion, and is supposed to benefit local communities (Zielenbach, 2002). The importance of this approach is reflected in the Leipzig Charter on Sustainable European Cities signed by EU members states' ministries responsible for urban development. The document places special emphasis 
on deprived neighbourhoods and issues of social integration. It proposes tools like social housing, strengthening the local economy and training for local communities (Leipzig Charter, 2008[AQ4]). The consensus on how the revitalisation should happen does not automatically result in the implementation of socially oriented intervention across the continent. Many authors doubt the ability of revitalisation to trigger a development process which would benefit different social groups in an equitable way (Temelová, 2009). This is visible especially in property-led development which concentrates predominantly on beautification and physical upgrading (Turok, I992) rather than on holistic bottom-up work with deprived communities. As illustrated by various Western European examples of projects of those types, rather than stimulating social inclusion, they often link to gentrification. Similar deviations of the revitalisation approach have become a big concern in CEE cities. However, next to emblematic examples illustrating the strong impact of gentrification, like the Prenzlauerberg district in Berlin (Holm, 2006), there are a number of less straightforward case studies. Hence in the CEE context some authors hesitate to take this perspective for analysing ongoing urban transformation (Haase et al., 2012). For instance, systematic research on several projects targeting inner-city regeneration in Budapest showed that gentrification was not their principal result. The displacement of lower-income residents was rare and happened mainly in state-led regeneration programmes (Kovács et al., 2012). Finally, even in the primary cities of the region one can find less attractive or historically deprived inner-city areas. They are still as run-down as they were in the middle of the transformation period, which suggests that the extent of regeneration projects and gentrification has not had a holistic impact on inner cities. Mono-functional cities like Lódź or Katowice in Poland have experienced slightly different patterns of development. In fact, while the 'successful' cities like Budapest have so-called 'bad districts' which are spatially limited, the majority of the Lódź inner city is considered to be deteriorating. If gentrification occurs there it rather takes the form of 'facade' or 'pocket' gentrification (Marcińczak, 2007). In this context, prospective socially oriented interventions in CEE might still benefit from rich international experience and propose alternative revitalisation solutions which could work against gentrification effects.

\section{2. Łódź: socio-economic context}

Łódź is the third-biggest city in Poland with 7II,300 inhabitants in 2013 (Statistical Office in Lodz, 20I4a), located in the exact centre of the country, I20 kilometres west of the capital city, Warsaw. The city experienced rapid development in the nineteenth century when, in just a hundred years, it was transformed from a minor town into the economic centre of the region. Back in the day it was labelled a Polish Manchester and identified with spectacular fortunes as well as major inequality and working-class 
struggle. The events of the Second World War dramatically reshaped Łódźs multicultural population structure, turning it into mono-ethnic Polish city. Even though the inner city did not suffer significant destruction during the war, relevant investments were stalled as the main priority of the new authorities was to develop large-scale housing projects outside the city centre. The key economic driver - the textile industry - had continued to sustain the city's growth for almost fifty years until the fall of communism and subsequent closure of the Russian market. The closure affected the collapse of the most important local enterprises. Lack of employment opportunities, along with general depopulation trends, in the country resulted in a dramatic fall in the city's population. Consequently, between I988 and 20I the city lost I43,000 citizens and its projected population for 2015 was 699,093 (Statistical Office in Lódz, 20I4b).

The change of economic system in 1989 and suburbanisation processes contributed to further impoverishment and depopulation of the inner city. Already in the I9gos systematic research identified the existence of seventeen poverty enclaves within Łódź, twelve of them within its inner city (Warzywoda-Kruszyńska, 1998). These areas were characterised by over 30 per cent of households using social care services, high unemployment, lower education levels and arguably higher crime rates. Similar observations have been made in the new millennium as the result of research in the whole inner city, illustrating the prevalence of social exclusion in the area (StelmachowiczPawyza and Swieżawska-Ambroziak, 2009). Likewise, the analysis of socio-economic status in Łódź revealed that six out of seven areas which were classified in the lower half of the ranking were located in the inner city. In contrast to major capital cities of the region, there was a tendency for people with higher socio-economic status to live in the suburban districts (Frykowski, 2004), which included not only the top-end areas but even a part of the large housing estates built in the socialist times.

\section{Urban planning in Łódź}

\subsection{Overview and methods}

The research in this paper aims at the identification of the main approaches to innercity regeneration in Łódź, as well as providing a review of how these approaches have transformed during the twenty-five years since the change of the political system in I989. Additionally the paper documents how the approaches have been implemented in practice.

Since the fall of the socialist regime there have been several documents at a national level with relevance to inner-city regeneration processes (such as the Spatial Planning and Development Act of 2003). However, these documents took the form of classical spatial planning instruments which did not enable implementation of comprehensive 
regeneration projects. Until recently, urban development and renewal in Poland have been considered municipal affairs with no related national or regional urban renewal policies or programmes (Franke et al., 2012; Scott and Kühn, 2012). Only in 2015 was there dedicated legislation when the Revitalization Act [AQ12] was adopted, introducing a number of instruments for steering the regeneration process (including tax incentives and a bureaucratic framework). The analysis conducted here pre-dates that Act. Reflecting the lack of comprehensive legislation at a national level before 20I5, only local-level documentation has been included in the review.

At a local level, three types of planning document are relevant for the city's spatial development: spatial studies, local spatial development plans and planning decisions, with the latter two being binding legal documents defining elements like land use, type of permitted development and so on (OECD, 2016). These instruments, with the exception of general guidelines outlined within spatial studies, do not define the particular strategic orientation and vision of the inner-city regeneration process. Rather, they provide a functional framework for implementation of external strategies and set a legal basis for the development of the built environment. As such, for the present analysis they were considered only a supplementary source.

Following the notion of strategic urban planning as a normative model guiding urban regeneration, a set of documents reflecting its main elements - vision, projects and partnerships (Scott and Kühn, 2012) - have been selected for analysis. The first element, vision, forms the central part. Consequently the key documents included are the ones defining overall city development strategies. The selection of this type of documentation allows us to review what was the focus on the inner-city regeneration among the different urban development priorities defined by the city authorities. It also enables us to trace how this focus has changed and to identify the evolution of the approaches to inner-city regeneration post-I989.

Four city-level strategy documents were included in the analysis. According to the current information provided by the City Office in Lódź, there have been two official, comprehensive strategies of that kind developed since the beginning of the I990s: the 1994 Strategy for the City and the 2012 Integrated Development Strategy for Łódź 2020+. Nevertheless the City Council resolution from I999, 'Concerning main assumptions for the city's development strategy and key activities of the city management during III term', as well as the 'Plan of the development of Łódź for the years 2007-2013', functioned as strategic documents and laid the foundations for several important programmes in the inner city. Consequently they are included in the analysis.

The analysis concentrated on the identification of objectives defining the focus of the strategies. This includes review $\left[\mathrm{AQ}_{5}\right]$ of two highest levels of objective which, in line with the Project Cycle Management Guidelines of the European Commission (European Commission, 2004) define the orientation of the strategies and projects, 
including

- overall objectives - defining their end purpose or the domain to which they contribute;

- specific objectives (purpose/goals) - reflecting more detailed and intermediary steps to be achieved.

Sections of the strategies describing their objectives have been identified and rigorously reviewed. If no such dedicated section existed, the entire documents were reviewed in order to identify the parts defining the objectives of the strategies. Based on the scope of the objectives and their further description in the reviewed strategies they were classified as:

I directly relevant (those which defined area/actions in the inner city as well as those which related to functions and issues most characteristic of the inner city),

2 strongly related (those which related to functions/issues which are relevant to the inner city but often occur outside it as well),

3 indirectly relevant (related to broader functions and issues on the city scale and not described in the strategies in the context of the inner city), and

4 with no tangible link to the inner-city regeneration process (not related explicitly to functions and issues in the inner city).

The analysis led to the identification of three approaches to inner-city regeneration which were represented within different objectives and categorised as culture-led development, mega-project, or socially focused revitalisation. Lastly, the review focused on identifying whether any specific programmes and projects with a focus on the inner city were proposed to be implemented within the strategies.

[AQ6] Section 5 aims at illustrating:

- How were the inner-city regeneration approaches identified within the strategies implemented?

- What was the relation between different approaches?

- What were their initial outcomes?

The implementation of specific projects is traced with the documentation listed in Table I as well as available secondary sources. This part of the analysis enabled the review of two remaining elements of the strategic planning model, the 'projects' and 'partnerships'. 
Table 1 Overview of overall and specific objectives of the city-level strategies

\begin{tabular}{|c|c|c|c|c|}
\hline Strategy & $\begin{array}{l}\text { Overall objectives with } \\
\text { relevance to inner-city } \\
\text { regeneration } \\
\text { (directly relevant, } \\
\text { strongly related, } \\
\text { indirectly relevant, no } \\
\text { tangible link) }\end{array}$ & Specific objectives & $\begin{array}{l}\text { Represented } \\
\text { approach: } \\
\text { 1. culture-led } \\
\text { development } \\
\text { 2. mega-project } \\
\text { 3. socially focused } \\
\text { revitalisation }\end{array}$ & $\begin{array}{l}\text { Programmes and } \\
\text { projects resulting } \\
\text { from the strategy }\end{array}$ \\
\hline 1994 & $\begin{array}{l}3 \text { 'Values/elements' of } \\
\text { the strategy listed, } \\
\text { none with tangible } \\
\text { link to inner-city } \\
\text { regeneration }\end{array}$ & - & - & - \\
\hline 1999 & $\begin{array}{l}6 \text { listed, } 1 \text { strongly } \\
\text { related, } 5 \text { indirectly } \\
\text { relevant } \\
\text { Strongly related: } \\
\text { 'Enhancement } \\
\text { and development } \\
\text { of metropolitan } \\
\text { functions': cultural } \\
\text { activities seen as an } \\
\text { element of metro- } \\
\text { politan function of } \\
\text { the city }\end{array}$ & $\begin{array}{l}6 \text { listed, } 1 \text { directly relevant, } 5 \\
\text { indirectly relevant } \\
\text { Directly relevant: } \\
\text { 'Delimitation of prestige areas: } \\
\text { around main train station, } \\
\text { Piotrkowska street and industrial } \\
\text { heritage zones' }\end{array}$ & $\begin{array}{l}2,3 \\
1 \text { (mentioned } \\
\text { indirectly within } \\
\text { overall objective) }\end{array}$ & $\begin{array}{l}\text { 'Simplified Local } \\
\text { Revitalization Plan } \\
\text { for the Selected } \\
\text { Inner City Areas } \\
\text { for the years } \\
2004-2013 \text { ' }\end{array}$ \\
\hline \multirow[t]{4}{*}{2007} & $\begin{array}{l}3 \text { overall objectives - } \\
\text { all strongly related to } \\
\text { inner-city regeneration }\end{array}$ & $\begin{array}{l}14 \text { listed, } 3 \text { directly relevant, } 1 \\
\text { strongly related, } 8 \text { indirectly relevant, } \\
2 \text { no tangible link }\end{array}$ & & \\
\hline & $\begin{array}{l}\text { I. Improving competi- } \\
\text { tiveness of the city }\end{array}$ & $\begin{array}{l}\text { Directly relevant: } \\
\text { 'Increasing city attractiveness': } \\
\text { including the creation of strategy of } \\
\text { the city as a 'city of culture and the } \\
\text { arts' with the focus on multicultur- } \\
\text { ality, music (clubbing), visual arts }\end{array}$ & 1 & $\begin{array}{l}\text { Application for } \\
\text { European Capital } \\
\text { of Culture ( } 2010 \text { - } \\
\text { not successful) } \\
\text { Strategy of } \\
\text { Promotion of Łódź } \\
\text { Brand (2010) }\end{array}$ \\
\hline & $\begin{array}{l}\text { II. Improvement of } \\
\text { the quality of life in } \\
\text { the city }\end{array}$ & $\begin{array}{l}\text { Directly relevant: } \\
\text { 'Revitalisation and development of } \\
\text { housing' including: } \\
\text { Revitalisation of inner-city area } \\
\text { between Piotrkowska-Tuwima- } \\
\text { Kilińskiego-Piłsudskiego streets (see } \\
\text { Figure 5), } \\
\text { Revitalisation of EC1 and its adapta- } \\
\text { tion on cultural and artistic goals, } \\
\text { Creation of Special Art Zone, } \\
\text { Revitalisation of family housing }\end{array}$ & 2,3 & $\begin{array}{l}\text { New Centre of Łódź } \\
\text { Programme (2007) } \\
\text { Revitalization of } \\
\text { Family Housing } \\
\text { Programme (2007) } \\
\text { Integrated } \\
\text { Programme of } \\
\text { Revitalisation of } \\
\text { Księży Młyn Area } \\
\text { (2010) } \\
\text { City of Tenement } \\
\text { Houses (2011) }\end{array}$ \\
\hline & $\begin{array}{l}\text { III Creation of } \\
\text { high-quality social } \\
\text { environment }\end{array}$ & $\begin{array}{l}\text { Directly relevant: } \\
\text { 'Decreasing poverty areas and } \\
\text { counteracting social exclusion'. } \\
\text { Strongly related: } \\
\text { 'Counteracting unemployment and } \\
\text { activation of local employment } \\
\text { market' }\end{array}$ & 3 & $\begin{array}{l}\text { Social Revitalisation } \\
\text { Strategy (2009) }\end{array}$ \\
\hline
\end{tabular}




\begin{tabular}{|c|c|c|c|c|}
\hline Strategy & $\begin{array}{l}\text { Overall objectives with } \\
\text { relevance to inner-city } \\
\text { regeneration } \\
\text { (directly relevant, } \\
\text { strongly related, } \\
\text { indirectly relevant, no } \\
\text { tangible link) }\end{array}$ & Specific objectives & $\begin{array}{l}\text { Represented } \\
\text { approach: } \\
\text { 1. culture-led } \\
\text { development } \\
\text { 2. mega-project } \\
\text { 3. socially focused } \\
\text { revitalisation }\end{array}$ & $\begin{array}{l}\text { Programmes and } \\
\text { projects resulting } \\
\text { from the strategy }\end{array}$ \\
\hline \multirow[t]{6}{*}{2012} & $\begin{array}{l}3 \text { 'pillars' all strongly } \\
\text { related to inner-city } \\
\text { regeneration }\end{array}$ & $\begin{array}{l}10 \text { specific objectives: } 2 \text { directly } \\
\text { relevant, } 6 \text { strongly related and } 2 \\
\text { indirectly relevant. }\end{array}$ & & \\
\hline & $\begin{array}{l}\text { I. Economy and } \\
\text { Infrastructure }\end{array}$ & $\begin{array}{l}\text { Directly relevant: } \\
\text { 'New Centre of Łódź - realisation } \\
\text { of the vision including creation of a } \\
\text { modern area of social and economic } \\
\text { activity with very good accessibility'. } \\
\text { Strongly related: } \\
\text { 'Functional Łódź metropolis which } \\
\text { fully exploits its potential arising from } \\
\text { the central position in Europe and } \\
\text { Poland' } \\
\text { 'Enterprising, creative and innovative } \\
\text { Łódź - development in the Łódź } \\
\text { agglomeration of economy based on } \\
\text { knowledge, innovation and creative } \\
\text { ideas, exploiting the scientific and } \\
\text { entrepreneurial potential of Łódź } \\
\text { with the focus on supporting creative } \\
\text { industries' }\end{array}$ & 2 & \\
\hline & II. Society and Culture & $\begin{array}{l}\text { Strongly related: } \\
\text { 'City common good - building } \\
\text { of high-quality social capital and } \\
\text { development of Łódź citizens' } \\
\text { participation' } \\
\text { 'Culture at the heart increasing } \\
\text { residents' participation in culture } \\
\text { through effective exploitation of } \\
\text { cultural and creative potential of } \\
\text { Łódź' }\end{array}$ & 1,3 & \\
\hline & $\begin{array}{l}\text { III. Space and } \\
\text { Environment }\end{array}$ & $\begin{array}{l}\text { Directly relevant: } \\
\text { 'Regeneration of the city centre - } \\
\text { improvement of Łódź citizens' quality } \\
\text { of life through enhancement of } \\
\text { attractiveness of the central areas of } \\
\text { the city, through reconstruction of the } \\
\text { historic urban fabric with conferment } \\
\text { of new functions on it' } \\
\text { Strong related: }\end{array}$ & 3 & $\begin{array}{l}\text { Local Revitalization } \\
\text { Programme, tódź } \\
2020+(2015)\end{array}$ \\
\hline & & $\begin{array}{l}\text { 'City of sustainable transport } \\
\text { improvement of the quality of life } \\
\text { and economic attractiveness of } \\
\text { the city through development of a } \\
\text { friendly and sustainable system of } \\
\text { public transport, integrated on a } \\
\text { scale of the Łódź Metropolitan Area'. }\end{array}$ & 2,3 & \\
\hline & & $\begin{array}{l}\text { 'Safe city - increase in the level } \\
\text { of security, improvement of public } \\
\text { order, cleanliness and aesthetic } \\
\text { characteristics of the city' }\end{array}$ & 3 & \\
\hline
\end{tabular}




\subsection{Limitations of the study}

The key limitation of the study relates to the early phases of inner-city development in the I99os, which lacked a single coherent vision. Planning documents like the local spatial development plans were to a large extent absent, which enabled the private sector to have a powerful and haphazard influence on the city's built environment. Additionally, the binding document 'Strategy for the City' from I994 provided a very generic and limited orientation for the city's development. The overall and specific objectives are not listed explicitly but defined as 'values' and described in a general 'narrative' way, and have been identified by the author through a detailed review of the text. Similarly the I999 strategy includes a category of 'long-term activities' which are identified here as specific objectives and included in the analysis.

While the lack of relevant strategies already provides important information about this phase of the city's development, the lack of overarching planning documents and legislation suggests many decisions were made at municipal office departmental level. For this reason the analysis of the early period is supported by secondary sources and literature which enabled some of these activities to be traced.

\subsection{The whole picture: three approaches to inner-city regeneration}

As a result of analysing the process of transformation of the existing city-level strategies in Łódź, two processes are worth noting. First, the quality of strategies improved over time with the initial I994 strategy being a 'vision document' rather than a real strategy which could steer the work of municipal offices. Over time the issue was addressed and from 2007 onwards the documents contained well-organised plans which guide the establishment of relevant programmes and projects. Second, in terms of the contents, one can notice an increased focus on the issues evident in the inner city. While the strategies from the rg9os signify that one of the main problems in Lódź is the deterioration of its central zone, the 200os-20Ios strategies genuinely attempt to propose solutions for its regeneration. The initial focus in the rggos lies in the culture-led development approach with initial ideas about the promotion of the city through replication of the myth of the 'Polish Manchester', 'promised land for entrepreneurial people', as well as historical multiculturalism. The approach has continued until the present day; however, with time, the focus has shifted to the concept of the creative city and alternative arts. Although the strategy from 2007 also referred to the city traditions, including the world-famous Lódź Film School and twentieth-century avant-garde arts, the inspiration provided by Richard Florida's concept of creative classes is evident. Like some UK cities, the urban fabric filled with neglected industrial spaces was perceived as a great resource for the development of a creative-based economy. A variety of loosely connected initiatives emerged out of this strategic orientation which, in this paper, will be categorised as culture-led development. 
The urban mega-project was introduced solely as a culture-led initiative involving the redevelopment of an old power station, EGI, into a cultural centre and the David Lynch film studio. However it evolved into a huge infrastructural project which was an extremely important element of the city strategy from 2007 onwards. In the years 2007-2015 the project remained the biggest and most expensive investment in the city. Although the contents of the project have significantly changed during its course, the 2012 strategy still positioned it as a key initiative for the city.

The third approach, 'social revitalisation', is in sharp contrast to the other two approaches. It was originally mentioned in the I999 strategy and began to take shape in 2004 through the first area-based revitalisation programme. It offered a different perspective on inner-city regeneration which would take place not only through promotional efforts or as a counterbalance to major investment, but rather as a longterm systematic effort to reduce existing social issues and poverty. It was strongly reinforced in the 2012 strategy and, in 20I5, linked to the recent Revitalization Act [AQ12] and a massive programme of the revitalisation of Lódź inner city.

\section{The application of the strategies}

\subsection{Culture-led development: from demolition to creative industries}

The strategic focus on culture was already prominent in the Ig9os, when the authorities approved several plans and facilitated a number of initiatives centred on the theme of the city's history. The 1992 Spatial Plan of the City of Lódź underscored the relevance of the 'regeneration of cultural space and the creation of an emotional attachment between its inhabitants and their city' (Young and Kaczmarek, I999, I85). Furthermore, the Strategy for the City (1994) and Promised Land - Once Again campaign (I995) developed by the Department of City Strategy were intended to link current developments of the city with the urban heritage and 'golden' traditions of the nineteenth-century metropolis - a 'promised land' for entrepreneurs of all nationalities (Young and Kaczmarek, I999). However, in spite of this narration and the plans to regenerate the cultural spaces of the city, the 'legal' and illegal demolition of factories was a more prominent manifestation of the city's approach to the industrial heritage of nineteenth-century Łódź (Zysiak, 20ıo). During this period several impressive pearls of industrial architecture were irreversibly lost.

By the start of the twenty-first century, the narrative focus in the city's promotion had gradually shifted towards tolerance and the cultural diversity of pre-war Łódź. As stated by the former director of the Strategy and Analysis Department of the Łódź City Office,

Łódź was a multicultural, tolerant town. A memory of that multicultural character ought to be inculcated into the public consciousness, it ought to be turned into a public, 


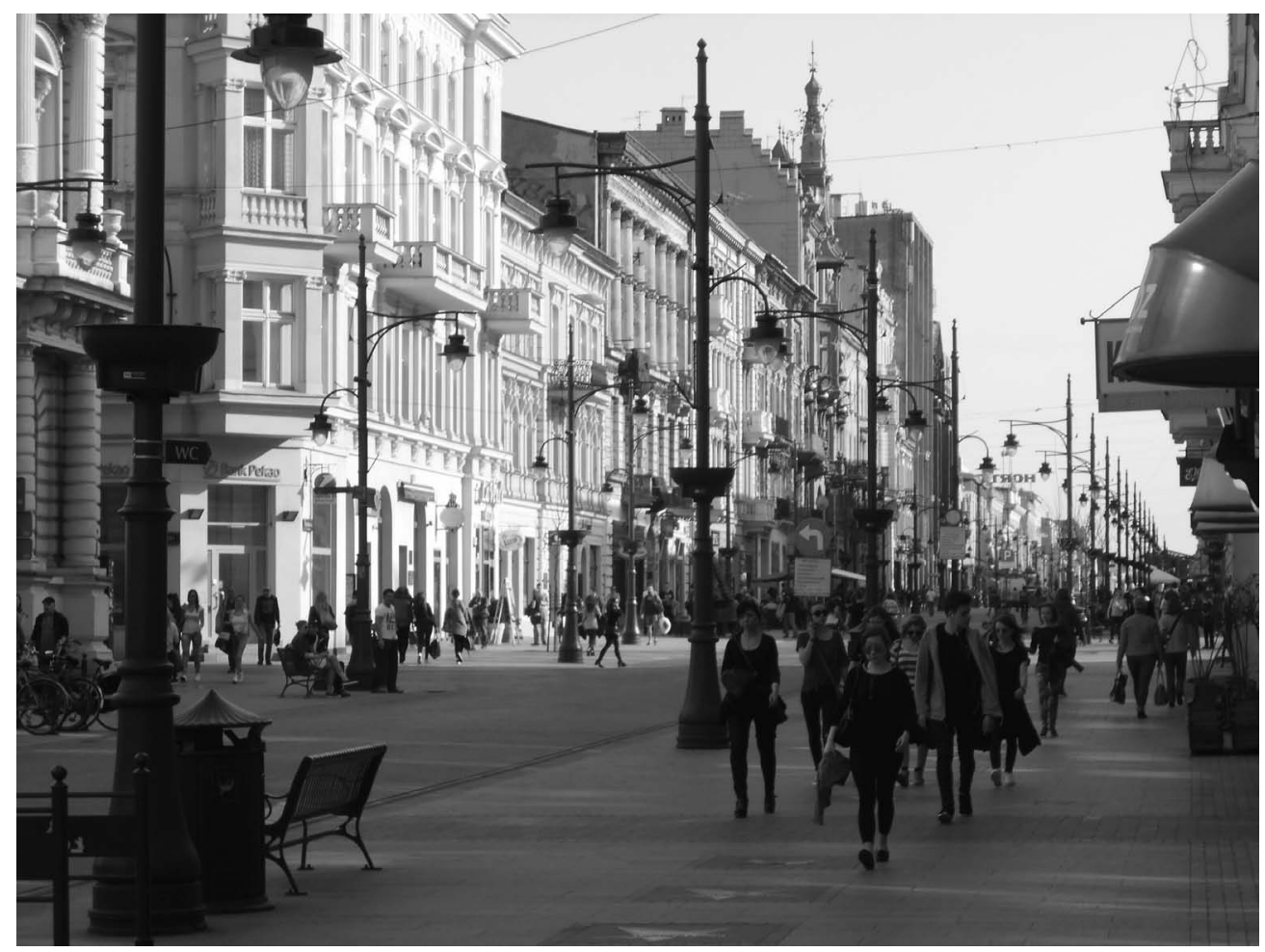

Figure $1[A Q 7]$

media, tourist product, even though material centres of this phenomenon hardly exist any more. (Michalski, 2006, I)

This strategy was manifest in a number of festivals which took place in the city centre and were used as a tool for its activation. In 2002, the annual Festival of Dialogue of the Four Cultures (Polish, Jewish, German and Russian) was initiated. In 2004 the city celebrated the Year of Jewish Culture and History and in 2005 the Year of German Culture and History' (Young and Kaczmarek, 2008). Additionally, the visual space of the city has been enriched by monuments and museums, a reminder that Łódź was once a multicultural city (Galuszka, 20I3). This includes the notable example of Survivors Park, opened in 2004 and devoted to Poles who saved Jews during the Second World War.

The scope of culture-led development initiatives gradually shifted to 'alternative' Łódź and creativity, which linked to the traditions of the Lódź film industry (Brzozowska, 20i6). The Camerimage film festival (2000-2009) gained strong recognition. Some bottom-up initiatives like the Łódź Design Festival and the Łódź Photo 


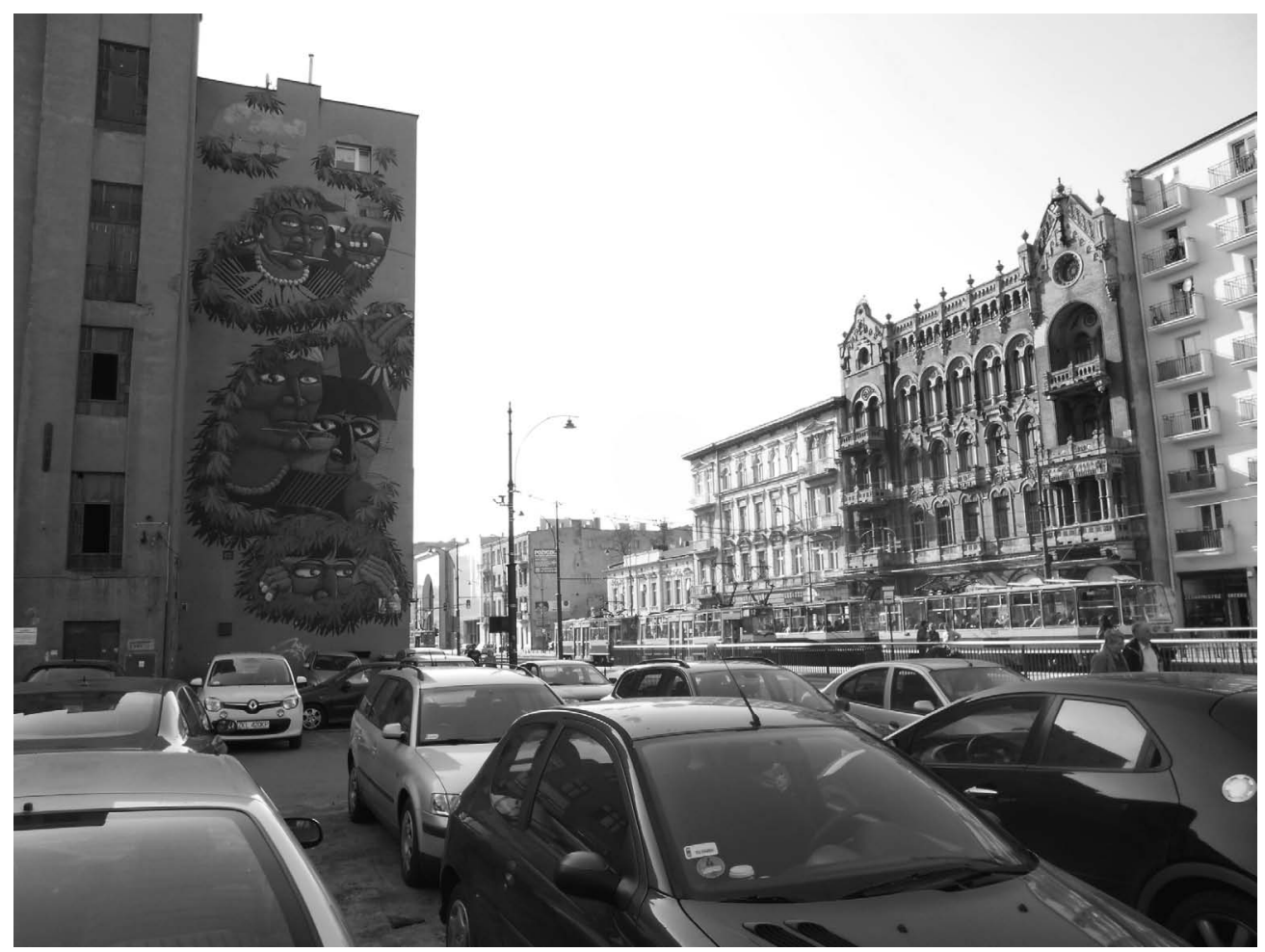

Figure $2[A Q 7]$

Festival, as well as the Urban Form Gallery (the creation of large murals across the city; see Figure 2) were started in 2002 and 2009 respectively and have been strongly supported by the city.

Similarly, around 20I0, various creative-industry sectors, especially the design and film industries, were promoted. The recurrent theme of culture-led development was reinforced in 2010, when the new Strategy of Promotion of the Eódź Brand was approved by the City Council and the application for designation as European Capital of Culture 2016 was submitted. The strategic objective of the former was to create 'the image of Łódź as a Creative Industries Centre on the perceptual map of Poland, Europe and the world' and to create 'the image of a creative, energetic, open, entrepreneurial, independent and bold place' (Urząd Miasta Lodzi, 20ı, 62).

Overall the strategic documents analysed, together with the festivals and spatial interventions, illustrate just how seductive for the city authorities were Florida's concept of creative classes and the narrative of a tolerant, open city. In spite of these efforts, the European Capital of Culture 2016 title was won by Wrocław, which applied a similar 
strategy. Additionally, the trust of the city authorities in the impact of the culture-led regeneration approach may be overshadowed by common contestation of the values promoted by the urban development strategies. The official narrative is contradicted by the numerous racist graffiti dominating the inner-city spaces (Galuszka, 2009). Similarly, according to the research concerning the proposed elements of the New Centre of Łódź project, the only one which received dominant negative feedback was the construction of the streets of Four Cultures (Polish, Jewish, German and Russian) (Krzewińska, 20I0). In this context it seems that the culture-led component of the regeneration strategy is rather supposed to attract tourists and 'elite' migrants to the city, or to convince the incoming students that it is interesting to live in the city. The 'creative', avant-garde and previous multiculturalism components are indeed of little interest for the majority of citizens of this predominantly working-class city.

\subsection{New Centre of Łódź: a mega-project}

The New Centre of Łódź (NCL) mega-project concerns the development of an approximately hundred-hectare area in the city centre. The idea of the project has been linked with the establishment of the World Art Foundation in 2006 by a local businessman, along with a curator of the Camerimage movie festival and the famous film director David Lynch. Of those three stakeholders the local ones were very influential in shaping the project in its first years. Initially, they planned to redevelop a disused power station (EGi) into a cultural centre and film studio. The idea coincided with the plans of the Polish Railway Company (PKP) and the city authorities to redevelop a central, terminal railway station into an underground station and the creation of a railway network under the centre of the city. Like many Western European transitoriented projects (Desjardins et al., 2014), both proposals merged into an ambitious concept of redeveloping liberated brownfield land and a railway zone into a high-end district mixing cultural, transport and business functions.

The City Council legitimised and defined the process through the Resolution Implementing the New Centre of Łódź Programme (Urząd Miasta Lodzi, 2007 [AQ8]). At this stage the concept had already been presented to the citizens, although they had virtually no impact on its shape. In fact, as opposed to some western projects HafenCity in Hamburg, the city did not own all the land before announcing the project, but proceeded to purchase it during the planning and implementation stages of the project. In part, this could have been motivated by the deadlines for EU funding which reversed the sequence of investment and rushed provisional agreements between the involved stakeholders. At the same time, the lack of a consultation phase could be put down to ignorance of public authorities rooted in the inheritance of socialist planning. Similarly, the poor participatory aspect links to the lack of a tradition of civic engagement, which can also be identified in other post-socialist cities 
(see Hirt, 2005). As a consequence, the authorities and two aforementioned stakeholders from the business and arts sectors crafted a plan for a 'cultural quarter' and a 'business quarter' located around a new multimodal transport node. The former was planned to include several revitalised and new buildings with a cultural function. A more detailed plan for the cultural quarter was proposed by Rob Krier, which embodied the ambition of the main stakeholders to create a new 'old town' with a market square and four narrow streets named Polish, Jewish, German and Russian, clearly referring to the myth of nineteenth-century multicultural Łódź.

In the 'business quarter' the construction of a new high-rise business district was planned. This was justified by the planned shortened travel time to the centre of the capital city, Warsaw, and the proposed construction of a tunnel under the city centre which would enable Łódź to be connected to the planned Fast Railway Network and the developing Łódź Metropolitan Railway system. As a consequence, the initially planned area of office space was estimated at an unrealistic level of a minimum 734,000 square metres and a maximum 1,528,000 square metres. This contrasted sharply with the overall amount of office space available and under construction in Łódź in 20I0, reaching a total area of around 250,000 square metres (Galuszka, 2010).

For the first five to seven years the project was developed along those lines, with the buildings and roads designed and funding sourced from EU, state and the city's budgets. The city's ambition to create iconic architecture was realised with the concept designs for the Special Art Zone and the Festival/Congress Hall, the latter planned to be designed by the famous architect Frank Gehry. The extravagant and expensive architecture was justified by the main stakeholders in terms of the supposed benefits to the city thanks to the expected 'Guggenheim Museum effect'. The proposal did not take into consideration that replicating the same idea in a different context might not work well (Kunzmann, 2004). While work on the station and redevelopment of the old power station went forward steadily, the other project started to enter a critical phase around 2010 or 20II. First, the opposition parties in the City Council questioned the costs of the planned Festival/Congress Hall by Frank Gehry. As a consequence, one of the main stakeholders threatened to take away the aforementioned Camerimage Festival from Łódź, which triggered protests and the occupation of the City Council by local students. This was the first time that the citizens got seriously involved in the project and, most interestingly, supported public spending on the investment rather than opposing it.

In fact, initially almost all aspects of the proposed projects received very strong public support (Krzewińska, 2010). While it is not uncommon for similar initiatives to receive substantial support in their initial stages, it might seem odd that the campaign supporting public spending came about in spite of the lack of a consultation phase at the beginning of the project. In the similar Stuttgart 2i project realised in Stuttgart, Germany, a massive protest against the project eventually took place, even though the consultation phase had been conducted in its initial stages. Along with its rising costs, 


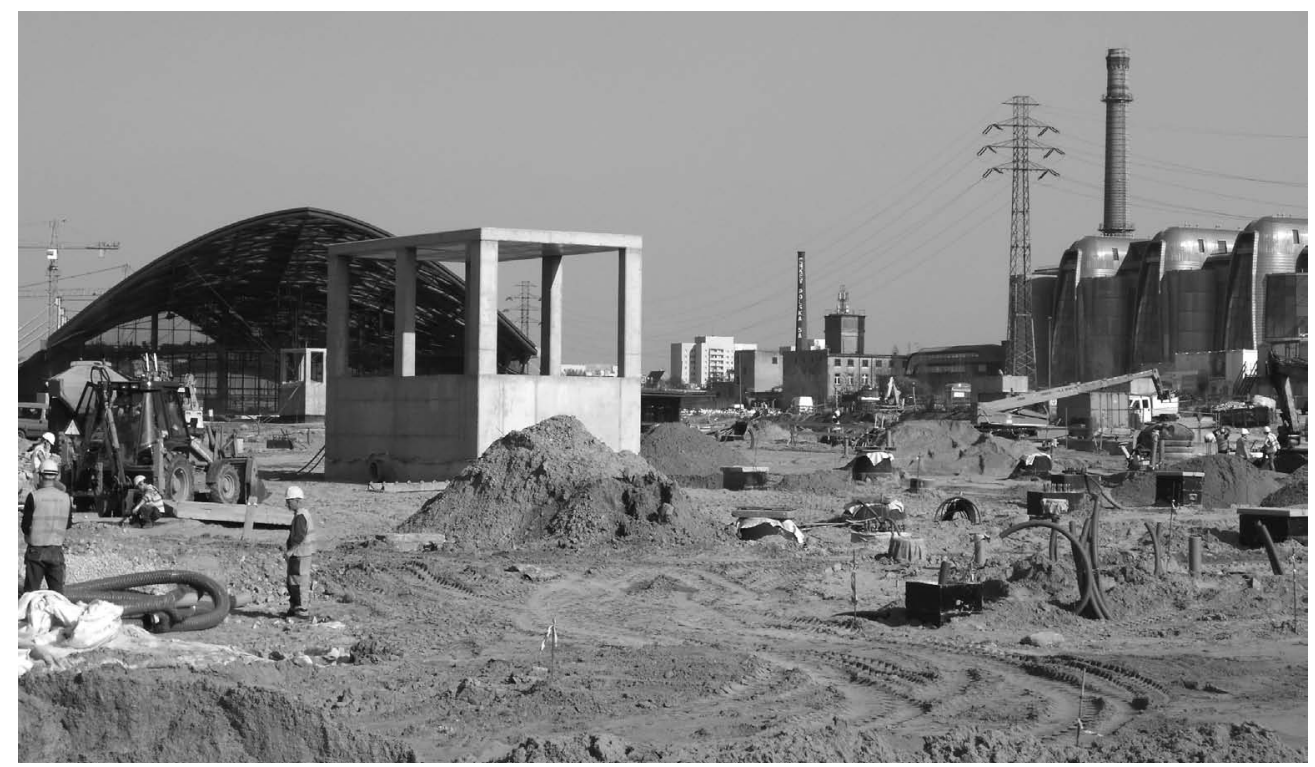

Figure 3 [AQ7]

support for the project has progressively declined and its elements were requested to be downscaled (Novy and Peters, 2012).

In Łódź, several components of the project failed or were eventually scaled down due to internal conflict, but not because of social control. Public meetings held from 20 Io onwards and some consultation exercises with the public, students and academia were initiated. In spite of failing to realise two iconic architecture projects, the authorities and the involved stakeholders kept on pushing for extravagant architecture. Most recently they proposed a 'gate to the city' project with a structure in the style of La Défense, following up the 'Old City' fantasy foreign to Lódź planning traditions. In line with the city's specification, the concept design was proposed by Daniel Lebeskind and offered along with the land to potential investors. Finally, after a couple of failed tenders, a private company decided to construct the building in the form of the 'gate', yet with an arguably cheaper non-Lebeskind design.

In summary, the project went through significant transformation during its development. Although its socio-economic impacts cannot be evaluated at this point, some of its initial outcomes are already evident. The project obviously failed in terms of the ambitions to create iconic architecture, and experienced the conflicting interests of involved stakeholders and multiple delays, all of which were described by Bent Flyvbjerg as issues typical of mega-projects (Flyvbjerg, 20I4). The railway station and multimodal node were finalised in 2017 (Figure 3 ). 


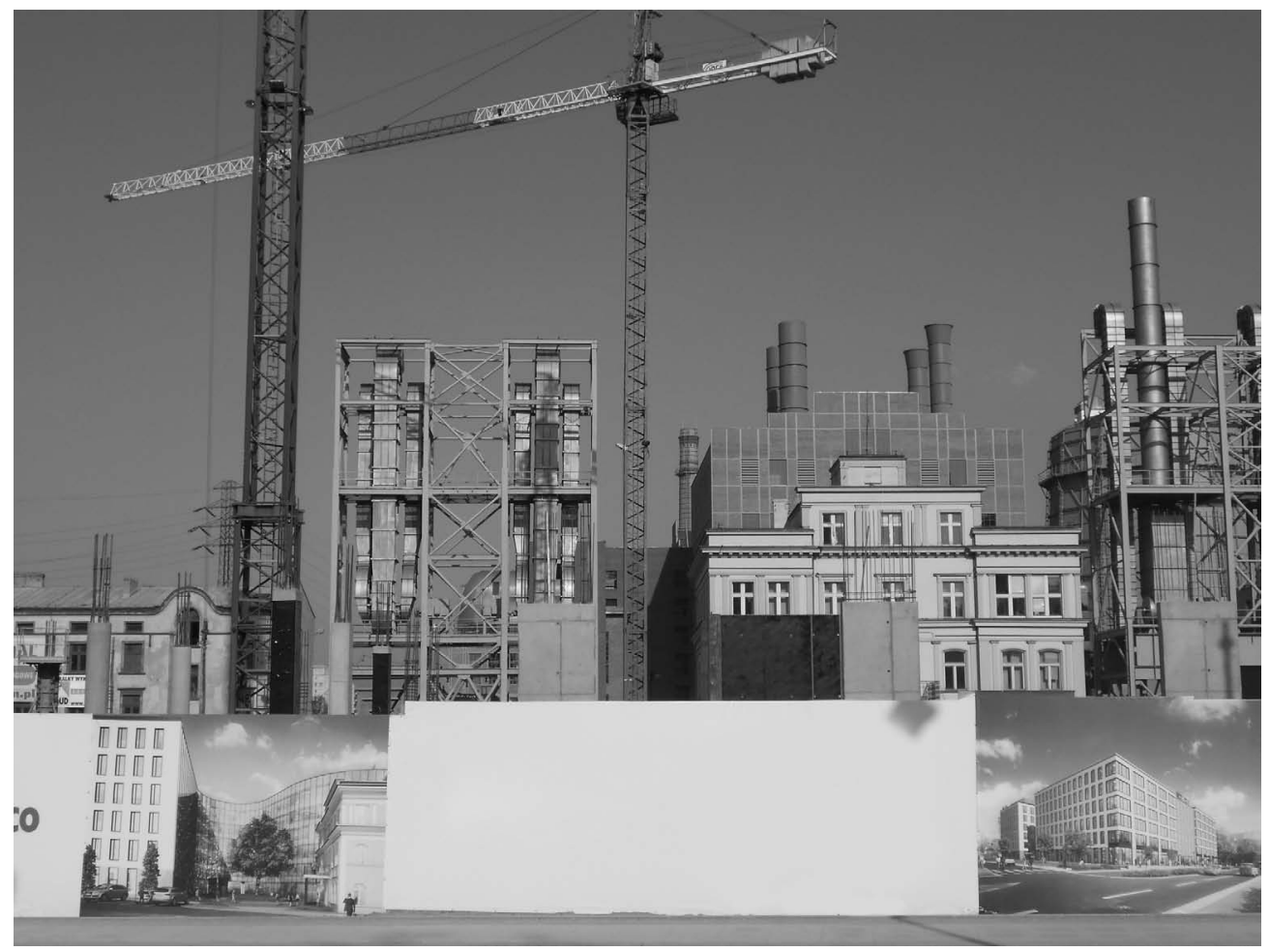

Figure $4[A Q 7]$

The other highly unrealistic element of the high-rise business district will not be realised. However, the project had already managed to attract some private investment. In 2015 three office buildings with a joint space of 80 ,ooo square metres were being constructed (Frak, 20I5). In addition, part of the redevelopment of the EGI power station (Figure 4) was finalised in 20I5 and, as of early 20I6, was considered a success.

\subsection{Social revitalisation}

The first manifestation of the social-revitalisation approach was the Local Revitalization Programme (LRP) (2004-2013) for the inner city. The programme identified a pilot area A (with two sub-areas: South and North) and three other areas, B, C and D (see Figure 5) (Urząd Miasta Łodzi, 2004).

The majority of projects took place within the first area, A South, characterised by high density and a central location. The funding between 2004 and 2006 was 
Figure 5 [AQ7]

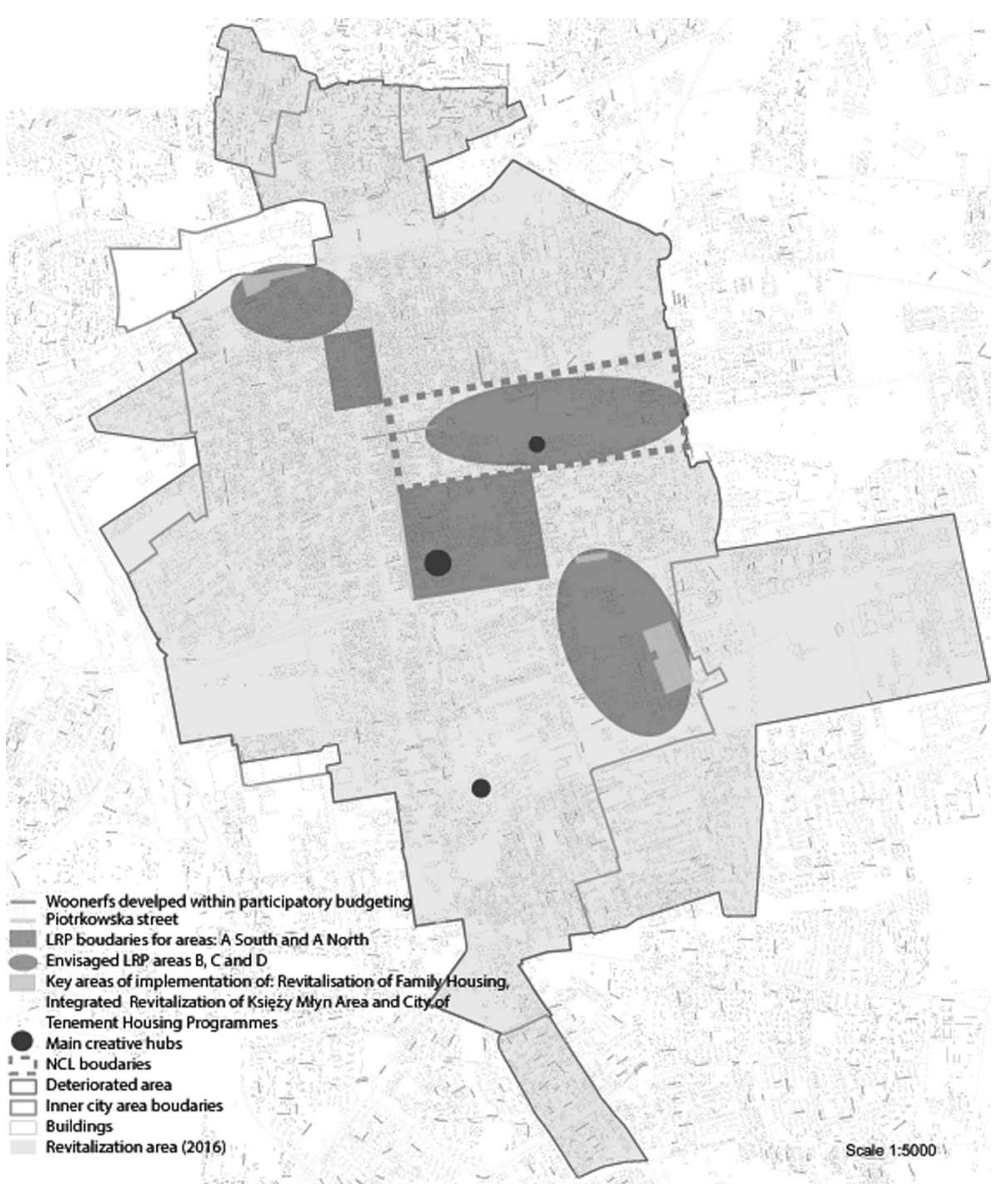

primarily devoted to infrastructure and housing, the latter developed with the support of the Social Housing Corporation which delivered small numbers of affordable flats. Probably, for the first time in the modern history of the city, a consultative component of the programme was trailed, although it was mostly limited to informing citizens and experts' consultation.

Three remaining areas identified in the LRP for redevelopment somewhat merged or were included in different programmes. Area B of the LRP was included in the New Centre of Łódź project. Areas C and D of the intervention specifically targeted family housing (nineteenth-century brick housing created for factory workers in the vicinity of the enterprises) and were included in the Programme of Revitalization of Family Housing. These activities were continued outside the original framework of the LRP, and although they have a declared social component, they supported 
the gentrification process. More precisely, the programme included renovation of housing in the target areas and selling it on the free market, if the current inhabitants agreed to move to substitute housing constructed by the private investor in a different location (Kowalska, 2010). At the same time, the programme in Księży Młyn (area D) included debt reduction opportunities and formed a social club in the district. It also incentivised the relocation of its inhabitants through preferential purchase and rent levels in the new housing (rent was kept at the same level as in previous, run-down housing). When linked with the opinion of the current president of the city, stating that the area should become 'a paradise for artists, creatives and visionaries, who would like to realise their projects' (TVN24, 2014) it becomes obvious that the city has not given up on the 'creative-classes' approach and has linked it to revitalisation discourse. Similarly, area C of the LRP has evolved into a City of Tenement Houses Programme and has been realised since 20II, with an intention of 'eliminating social housing through its removal from the inner-city district' (Urząd Miasta Łodzi, 2013) (so advocating gentrification in a very straightforward manner).

Regardless of the inconsistency in understanding the revitalisation in Lódź, the experience of the programmes described here set a basis for initiatives with stronger

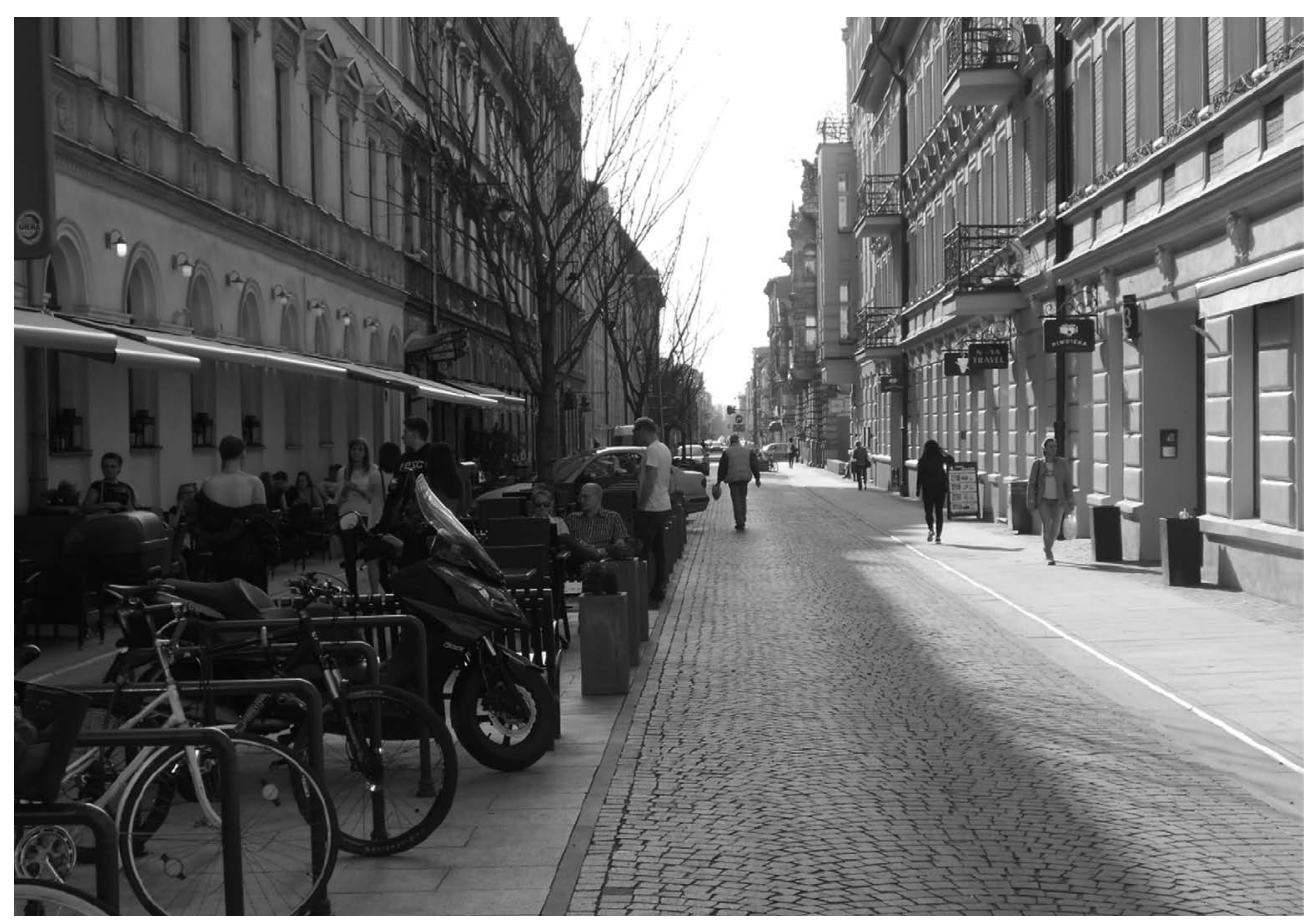

Figure $6[A Q 7]$ 


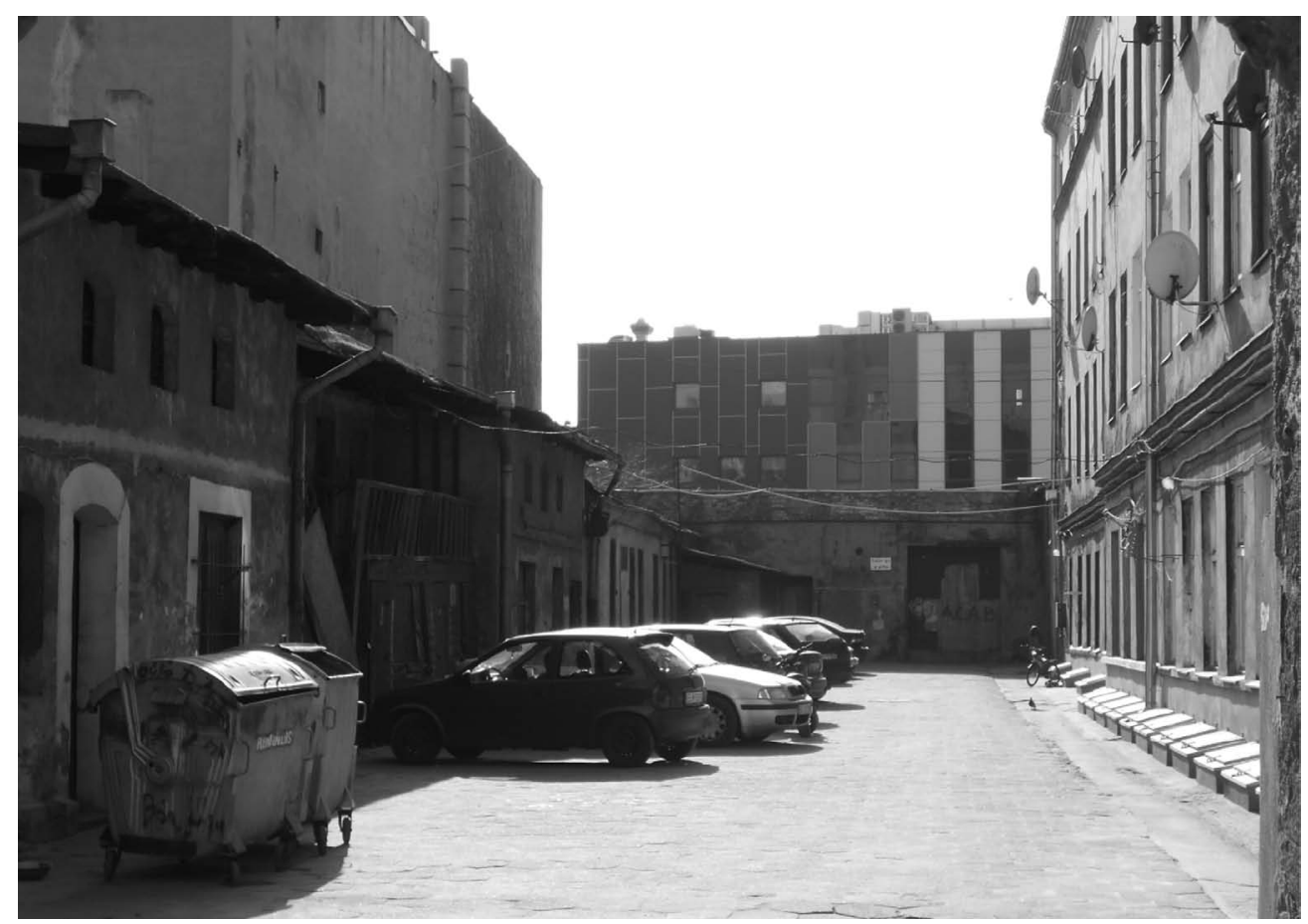

Figure 7 [AQ7]

participatory and social components and provided the opportunity for rising city movements and NGOs. These movements became more evident and involved in governance after 20I0, when the city population voted out Łódź's previous president in a common referendum. Since then, the authorities have been more open to innovative approaches, like the establishment of Brazilian-inspired participatory budgeting, with an annual fund of approximately $€_{\mathrm{I}}$ o million (Stokfiszewski, 20I5) which has enabled pedestrianising and beautification of some central spaces in the inner city (Figure 6).

The shift in thinking about the social aspects of revitalisation became even more visible around 2013 when the city started to plan an enormous new revitalisation programme for the entire inner city. The whole process consists of strong social components, participatory-planning workshops and consultations and a rent control system. Initially it also got support from the city movements and activists whose representatives were directly appointed in the city office. Finally, at the beginning of 2016, the initial funding for the programme was secured with a budget of around I billion PLN, including 650 million PLN from EU sources (Bujalski, 2016) which should provide ample opportunities for comprehensive inner-city regeneration (Figure 7). 
To sum up, the initial regeneration efforts labelled as social revitalisation have been, in many aspects, limited to the development of housing and infrastructure, with the minor addition of social programmes. While quite complex and innovative social revitalisation strategies have been developed, rather contradictory approaches to social support and relocation have been implemented in parallel. The projects labelled revitalisation of the inner city have often overlapped with culture-led development and the mega-project. Finally, it is hard to evaluate the effects of these projects, with out-migration remaining high and most of the housing stock still deteriorating. The latest ambitious revitalisation-oriented efforts might result in real change in the coming years, which will advance the understanding of participatory development and social regeneration in post-socialist cities. Certainly they do illustrate that, twentyfive years since the change of political regime, a slow shift in thinking about inner-city regeneration has taken place. Yet again, the latest initiative is not free of thinking about the city in terms of its global competiveness and hosting major events. After failing to become European Capital of Culture for 2016 the idea of inner-city regeneration is now linked to a planned application for the Small Expo in 2022 on the theme of revitalisation. One can only guess whether it is the revitalisation itself or the ambition to host a major event which is seen by the authorities as a remedy for the city's problems.

\section{Conclusions}

The review of the strategies and three resulting approaches relevant to inner-city regeneration in Łódź illustrate a dynamic transformation of local urban development in the twenty-five years since the change of the political system. The initial stage of inner-city regeneration in the I9gos has been characterised by haphazard investment by the private sector and the lack of a single coherent city development strategy. The strongest continuity can be seen in the systematic references to Lódź history and genius loci in two out of three identified regeneration approaches (cultureled development and mega-project). The pressure points of these references change over time and went from the entrepreneurial city narration to the multicultural city. However these two approaches not only refer to the city's history but also are strongly inspired by strategies from Western Europe. This is visible in the focus on the concept of creative classes at the programme level and a somewhat uncritical belief in the 'Guggenheim Museum effect' through the creation of iconic architecture. In this context the most relevant strategic innovation seems to link to the social revitalisation approach. With its pure gentrification focus in initial stages, as well as linkages with 'creative-classes' discourse, it illustrates that the implementation of truly socially oriented strategies requires several years of capacitation process in the city bureaucracy, among the NGO sector and arguably among citizens themselves. Only after 
twelve years of experimenting has the approach been scaled up and has a chance to address the everlasting problem in the inner city that has been poorly reflected in two other approaches: systemic poverty and detrimental housing conditions.

\section{References}

BRADE, I., HERFERT, G. and WIEST, K. (2009), 'Recent trends and future prospects of sociospatial differentiation in urban regions of Central and Eastern Europe: a lull before the storm?', Cities 26, 233-44.

BRZOZOWSKA, B. (2016), "Creative city" as a brand: the case of Lódź', Creativity Studies, 9, 3-14. BUJALSKI, S. (2016), Miliard na rewitalizacje Łodzi: Wreszcie! Gazeta Wyborcza Lódź, http:// lodz.wyborcza.pl/lodz/I,35I53,I94I944I,miliard-na-rewitalizacje-lodzi-wreszcie.html (accessed 2 January 20i6).

COLOMB, C. (2OII), 'Culture in the city, culture for the city? The political construction of the trickle-down in cultural regeneration strategies in Roubaix, France', Town Planning Review, 82, $77-98$.

DESJARDINS, X., MAULAT, J. and SYKES, O. (2014), 'Introduction. Linking rail and urban development: reflections on French and British experience', Town Planning Review, 85, I43-54.

Evans, G. and SHAw, P. (2004), The Contribution of Culture to Regeneration in the UK: A Review of Evidence, London, Department for Culture, Media and Sport.

European commission (2004), Aid Delivery Methods Volume I Project Cycle Management Guidelines, https://ec.europa.eu/europeaid/sites/devco/files/methodology-aid-delivery-methodsproject-cycle-management-200403_en_2.pdf (accessed i February 2011).

FLYVBJERG, B. (20I4), 'What you should know about megaprojects and why: an overview', Project Management fournal, 45, 6-I9.

FRANKE T., BÖHME C., STRAUSS W. C. and BEGKMANN K. (2012), 5 Years after the Leipzig Charter: Integrated Urban Development as a Prerequisite for a Sustainable City, Berlin, Federal Ministry of Transport, Building and Urban Development.

FRĄK, M. (20I5), 'Nowa siedziba mBanku: Biurowiec za Ioo mln zł w NCE', Gazeta Wyborcza Łódź, http://lodz.wyborcza.pl/lodz/I,35136,19028829,nowa-siedziba-mbanku-biurowiecza-ıoo-mln-zl-w-ncl.html\#ixzz3zi53xCVi (accessed i5 October 2016).

FRYKOWSKI, M. (2004), 'Zróżnicowanie przestrzenne statusu społecznego mieszkańców Łodzi', Studia Regionalne i Lokalne, $\mathbf{1 5}, 99-1 \mathrm{r} 8$.

GaluszKA, J. (2009), 'Przestrzeń manifestacji, czyli jak napisy na murach transformują przestrzeń miejską, Studia Regionalne i Lokalne, 35, IIo-26.

GALUSZKA, J. (20I0), 'Idea i cele przebudowy centrum Łodzi w kontekście społecznoprzestrzennej specyfiki miasta', in J. Galuszka (ed.), Wokót Nowego Centrum Lodzi, Lódź, EGi Łódź - Miasto Kultury, I3-4I.

GALUSZKA, J. (2013), 'Multicultural past as hope for the future? Spatial representations of the history of Lódź as an attempt to transform the city's image and identity', Ece-urban: The Online Publication Series of the Lviv Centre for Urban History of East Central Europe, II, I-2I.

HAASE, A., GROSSMANN, K. and STEINFÜHRER, A. (2012), 'Transitory urbanites: new actors of residential change in Polish and Czech inner cities', Cities, 29, 318-326. 
HIRT, S. (2005), 'Planning the post-communist city: experiences from Sofia', International Planning Studies, ro, 219-40.

HIRT, S. (2013), 'Whatever happened to the (post)socialist city?', Cities, 32, $\mathrm{S}_{29}-\mathrm{S}_{3} 8$.

HOLM, A. (2006), 'Urban renewal and the end of social housing: the roll out of neoliberalism in East Berlin's Prenzlauer Berg', Social fustice, 33, II4-28.

HOLM, A., MARCIŃCZAK, S. and OGRODOWCZYK, A. (20I5), 'New-build gentrification in the post-socialist city: Łódź and Leipzig two decades after socialism', Geografie, I 20, I64-87.

HUGHES, H., ALLEN, D. and WASIK, D. (2003), 'The significance of European "Capital of Culture" for tourism and culture: the case of Krakow 2000', International fournal of Arts Management, 5, I2-23.

KACZMAREK, S. and MARCIŃCZAK, S. (2013) 'The blessing in disguise: urban regeneration in Poland in a neo-liberal milieu', in M. E. Leary and J. McCarthy (eds), 98-1o6.

KERESZTÉLY, K. and SCOTT, J. W. (2012), 'Urban regeneration in the post-socialist context:

Budapest and the search for a social dimension', European Planning Studies, 2o, I I I I-34.

KOK, H. and KOVACS, Z. (I999), 'The process of suburbanization in the agglomeration of Budapest', Netherlands fournal of Housing and the Built Environment, 14, I19-4I.

KOVÁCS, Z. (1998), 'Ghettoisation or gentrification? Post-socialist scenarios for Budapest', Netherlands fournal of Housing and the Built Environment, $\mathbf{1 3}, 63^{-8}$ I.

KOVÁCS, Z., WIESSNER, R. and ZISCHNER, R. (2012), 'Urban renewal in the inner city of Budapest: gentrification from a post-socialist perspective', Urban Studies, 50, 22-38.

KOVACS, Z., WIESSNER, R. and ZISCHNER, R. (20I5), 'Beyond gentrification: diversified neighbourhood upgrading in the inner city of Budapest' Geografie-Sbornik Ceske Geograficke Spolecnosti, 1 20, 25 ${ }^{\mathrm{I}-74}$.

KOWALSKA, E. (20I0), 'Program rewitalizacji w Łodzi', in A. Muzioł-Węcławowicz (ed.), Przykłady rewitalizacji miast (seria 'Rewitalizacja miast polskich'), t. I2, Krakow, Instytut Rozwoju Miast, $233-64$.

KRZEWIŃSKA, A. (2010), 'Opinie łodzian o Nowym Centrum Łodzi', in J. Galuszka (ed.), 45-8o.

Kunzmann, K. (2004), 'Culture, creativity and spatial planning', Town Planning Review, 75, $383-404$.

LEARY, M. E. and MCGARTHY, J. (eds) (2013), The Routledge Companion to Urban Regeneration, London and New York, Routledge.

LEIPZIG CHARTER (2007), Leipzig Charter on Sustainable European cities, in European Conference of Ministers Responsible for Spatial/Regional Planning, Resolution 3.

MARCIŃCZAK, S. (2007), 'The socio-spatial structure of post-socialist Łódź, Poland: results of national census 2002', Bulletin of Geography, Socio-economic Series, 8, 65-82.

MARCIŃCZAK, S. and SAGAN, I. (2OI I), 'The socio-spatial restructuring of Lódź, Poland', Urban Studies, 48, I789-8og.

MARGIŃCZAK, S., MUSTERD, S. and STĘPNIAK, M. (2012), 'Where the grass is greener: social segregation in three major Polish cities at the beginning of the 2ist century', European Urban and Regional Studies, $\mathbf{1 9}, 383-403$.

MICHALSKI, w. (2006), 'Prawdziwość produktywnego mitu', Kronika Miasta Łodzi, 6, http://uml. lodz.pl/miasto/o_miescie/wydawnictwa_o_lodzi/kronika_miasta_lodzi/rok_20o6_ nr_I (accessed I3 June 2017).

MURZYN, M. (2006), "Winners" and "losers" in the game: the social dimension of urban 
regeneration in the Kazimierz quarter in Krakow', in G. Enyédi, and Z. Kovács (eds), Social Changes and Social Sustainability in Historical Urban Centres: The Case of Central Europe, Pécs, Hungarian Academy of Sciences and Centre for Regional Studies, 8I-Io6.

MURZYN, M. (2008), 'Heritage transformation in Central and Eastern Europe', in B. Graham and P. Howard (eds), The Ashgate Research Companion to Heritage and Identity, Aldershot, Ashgate, 315-46.

NOVY, J. and PETERS, D. (2OI2), 'Railway station mega-projects as public controversies: the case of Stuttgart 21', Built Environment, 38, I28-45.

OECD (2016), Governance of Land Use in Poland: The case of Lódz', Paris, OECD Publishing, at http:/dx.doi.org/ı.1787/9789264260597-en (accessed i November 2016).

ORUETA, F. D. and FAINSTEIN, S. S. (2008), 'The new mega-projects: genesis and impacts', International fournal of Urban and Regional Research, 32, 759-67.

PETERS, D. and NOVY, J. (2012), 'Train station area development mega-projects in Europe: towards a typology', Built Environment, 38, I2-30.

SCOTT, J. W. and KÜHN, M. (20I2), 'Urban change and urban development strategies in Central East Europe: a selective assessment of events since 1989', European Planning Studies, 2o, I093-IO9.

STATISTICAL OFFICE IN łÓDZ (20I4a), Łódź w liczbach 20I4, http://lodz.stat.gov.pl/publikacje-ifoldery/foldery/lodz-w-liczbach-2014,3,2.html (accessed 5 December 2015).

STATISTICAL OFFICE IN łÓDZ (20I4b), Statystyka Łodzi 20I4, http:/ /lodz.stat.gov.pl/publikacje-ifoldery/roczniki-statystyczne/statystyka-lodzi-20I4,4, I I.html (accessed 5 December 2015).

STOKFISZEWSKI, I. (20I5), 'We, the citizens: the rise of the Polish urban movements', Uncube Magazine, 3i, $34-43$.

STELMACHOWICZ-PAWYZA, D. and ŚWIEŻAWSKA-AMBrOZIAK, K. (2009), Spoleczna Strategia Rewitalizacji Raport z Badania, [AQ9] Lódź, Urząd Miasta Łodzi.

SYKORA, L. (I999), 'Changes in the internal spatial structure of post-communist Prague', Geofournal, 49, 79-89.

SYKORA, L. and BOUZAROVSKI, S. (2012), 'Multiple transformations: conceptualising the postcommunist urban transition', Urban Studies, 49, 43-6o.

TEMELOVA, J. (2007), 'Flagship developments and the physical upgrading of post-socialist inner city: the golden angel project in Prague', Geografiska Annaler, 89, г69-8г.

TEMELOVA, J. (2009), 'Urban revitalization in central and inner parts of (post-socialist) cities: conditions and consequences', in T. Ilmavirta (ed.), Regenerating Urban Core, Helsinki, Helsinki University of Technology, Centre for Urban and Regional Studies, I2-25.

T́ÖLLE, A. (20I0), 'Urban identity policies in Berlin: From critical reconstruction to reconstructing the Wall', Cities, 27, 348-57.

TUROK, I. (I992), 'Property-led urban regeneration: panacea or placebo?', Environment and Planning A, 24, 36I-79.

TVN24 (2014), Księży Mtyn nowq wizytówkq Łodzi? Nowe oblicze zabytkowego osiedla za $3 \mathrm{mln}$ złotych, www.tvn24.pl/lodz,69/ksiezy-mlyn-nowa-wizytowka-lodzi-nowe-oblicze-zabytkowegoosiedla-za-3-mln-zlotych,404299.html (accessed io November 2016).

URZĄD MIASTAłDZI(I994),[AQIo] Uchwała nr IV/29/94 rady miejskiejw Lodzizdnia I9 października I994, at http://bip.uml.lodz.pl/index.php?str=83\&id=49 (accessed I September 2016).

URZĄD MIASTA łODZI (I999), Uchwała nr XVI/277/99 rady miejskiej w Lodzi z dnia 2 czerwca I999, 
http://bip.uml.lodz.pl/index.php?str= ${ }_{1} 83 \& i d=6492$ (accessed 2 August 2016).

URZĄD MIASTA łODZI (2004), Uchwata nr XXXIV/o568/o4 rady miejskiej w Lodzi z dnia I4 lipca 2004 r. w sprawie przyjęcia Uproszczonego lokalnego programu rewitalizacji wybranych terenów śródmiejskich oraz pofabrycznych Łodzi na lata 2004 - 2013, http://bip.uml.lodz.pl/index. php? str $={ }_{1} 83 \& i d={ }_{1} 5236$ (accessed ı March 2016).

URZĄD MIASTA łODZI (2007a), Plan rozwoju lokalnego miasta Łodzi na lata 2007-2013, http://bip. uml.lodz.pl/_plik.php?id= ${ }_{7778} \&$ PHPSESSID $=($ accessed го March 20г6).

URZĄD MIASTA ЮDZI (2007b), Uchwała $\mathrm{nr}$ XVII/279/o7 rady miejskiej w Łodzi z dnia 28 sierpnia 2007 r. w sprawie przyjęcia Programu Nowe Centrum Łodzi, http://bip.uml.lodz.pl/_plik. php?plik=uchwaly/rm/o5_0279.DOC\&PHPSESSID=2bi I 4 aa4338е 3c283o82c5e7b6ci 4 ${ }_{4} \mathrm{f} 8 \square($ accessed $[A Q \mathrm{II}])$.

URZĄD MIASTA łODZI (2010), Łódź Brand Management Strategy for the Years 20I0-20I6, www. kreatywna.lodz.pl/data/dataPublicator/lodz_strategia_zarzadzania_marka_eng_I.pdf (accessed 5 March 20i6).

URZĄD MIASTA łODZI (20I I), Strategia zarzadzania marka Łodzi na lata 20I0-20I6, http://bip.uml. lodz.pl/_plik.php?id=27869 (accessed ı March 2016).

URZĄD MIASTA HODZI (2012), Resolution no XLIII/824/I2 of the City Council in Lodz of 25 June 2012 on Adoption of the 'Integrated Development Strategy for Łódz' 2020+', http://uml.lodz.pl/miasto/ strategia (accessed io March 20i6).

URZĄD MIASTA łODZI (20I3) 'Program "Miasto kamienic", http://bip.uml.lodz.pl/index. php?str $=9240 \&$ PHPSESSID $=6$ ee2047a8fabe39788IgaI332527cb6e (accessed I2 March 2016).

WALKER, A. R. (I993), 'Lodz: the problems associated with restructuring the urban economy of Poland's textile metropolis in the I990s', Urban Studies, 30, I065-80.

WARZYWODA-KRUSZYŃSKA, W. (ed) (I998) Żyć i pracować w enklawach biedy, Łódź, Instytut Socjologii.

YOUNG, C. and KACZMAREK, S. (I999), 'The changing meaning of place in post-socialist Eastern Europe: commodification, perception and environment', Geographical fournal, $\mathbf{1 6} \mathbf{5}$, I83-9I.

YOUNG, G. and KACZMAREK, S. (2008), 'The socialist past and post-socialist urban identity in Central and Eastern Europe: the case of Łodź, Poland', European Urban and Regional Studies, I5, $53-70$.

ZIELENBACH, S. (2002), The Art of Revitalization: Improving Conditions in Distressed Inner-City Neighborhoods, New York, Garland Publishing.

ZUKIN, S. (1998), 'Urban lifestyles: diversity and standardisation in spaces of consumption', Urban Studies, 35, 825-39.

ZYSIAK, A. (20I0) 'Trudne dziedzictwo: w poszukiwaniu tożsamości Łodzi', in J. Galuszka (ed.), Wokót Nowego Centrum Łodzi, Łódź, EGı Łódz' - Miasto Kultury, IO3-20. 